\title{
PEDAGOGŲ IR TÉVŲ BENDRADARBIAVIMAS UGDANT AUTIZMO SPEKTRO SUTRIKIMĄ TURINČIUS VAIKUS
}

\author{
Jüratè Kazlauskienè, ikimokyklinio ugdymo mokytoja \\ Šilutès lopšelis-darželis „, Žvaigždute““ \\ Aurelija Valaitiené, lektoré \\ Klaipédos valstybine kolegija \\ DOI: https://doi.org/10.52320/svv.vOiVI.192
}

\begin{abstract}
Anotacija
Daugelio autorių požiūriu pedagogų ir tėvų bendradarbiavimas ugdant autizmo spektro sutrikimą turinčius vaikus yra reikšmingas ir reikalingas procesas. Gilinantis ị pedagogų ir tèvų bendradarbiavimą ugdant autizmo spektro sutrikimą turinčius vaikus atskleidžiamos ivairios bendradarbiavimo problemos. Todèl išsikeltas probleminis klausimas, i kuri bandoma atsakyti - kaip vyksta bendradarbiavimas tarp pedagogų ir tėvųugdant autizmo spektro sutrikimą turinčius vaikus. Atliekant tyrimą buvo pasirinkti šie tyrimo metodai: mokslinès literatūros analizè, struktūrizuotas interviu, kokybinė tyrimo rezultatų analizè.

Straipsnyje nurodoma pedagogų ir tėvų partnerystès esmè ir prasmė, pagrindinių bendradarbiavimo nuostatų visuma, teoriniu ir praktiniu aspektu. Pedagogų nuomone, tėvų ịtraukimui ị ugdymo procesą priimtiniausios ir dažniausiai naudojamos bendradarbiavimo formos yra šios: individualūs pokalbiai ir susitikimai, bendri renginiai, šventès ir išvykos, šiek tiek rečiau ugdomosios veiklos ir susirinkimai. Pedagogai nurodo tokius bendradarbiavimo metodus ir priemones, susijusias su autizmo spektro sutrikimą turinčių vaikų tėvais: įvairūs susitikimai, pokalbiai, susirašinėjimas elektroniniais laiškais, ugdymosi pasiekimų vertinimas ir aptarimas.
\end{abstract}

Pagrindiniai žodžiai: autizmo spektro sutrikimas, tėvų ir pedagogų bendradarbiavimas, ugdymas.

\section{Ivadas}

Temos aktualumas. Autizmo spektro sutrikimas, dar vadinamas autizmu. Šis sutrikimas pasireiškia ankstyvojoje vaikysteje. Autizmo spektro sutrikimą nėra lengva atpažinti. Jis pasireiškia: sutrikusia socialine komunikacija, ribotu interesu buvimu ir pasikartojančiu elgesiu (Fett-Conte, Bassolani-Martins, Avanso Rosan, 2014). Šiuolaikiniame pasaulyje autizmo spektro sutrikimo tema yra plačiai žinoma, tačiau Lietuvoje šia tema mažai kalbama (Juchnevičienè, Mačiulienė, Juškytė, 2014). Autizmo spektro sutrikimai yra nevienalytė neurologinio vystymosi būklių grupė, pasižyminti nuolatiniais daugialypès socialinès komunikacijos ir sąveikos trūkumais (Aleksienè, Zvicevičienė, 2008).Autizmo spektro sutrikimo kilimo priežastys lieka neaiškios iki šių dienų (Grecucci, Siugzdaite, Job, 2016). Autizmo spektro sutrikimas gali sukelti didelių socialinių, bendravimo ir elgesio problemų. Vaikai turintys ši sutrikimą geba bendrauti, elgtis tinkamai ir mokytis, tačiau skirtingai nei dauguma kitų žmonių, vieniems reikia kasdieniniame gyvenime daugiau pagalbos, o kitiems - mažiau. Tik darnus pedagogų, tėvų ir specialistų bendradarbiavimas gali padèti vaikams sẻkmingai socializuotis visuomenejje (Encarnacion, Pozo, 2014). Pedagogai ir tèvai yradvi sąsajos, kurios atsakingos už mažo vaiko auklèjimą ir paruošimą savarankiškam gyvenimui. Jų bendradarbiavimas yra itin svarbus ir reikalingas, kadangi pedagogai ir tèvai tik dirbdami kartu gali pasiekti puikių rezultatų. Puikūs pedagogų ir tėvų tarpusavio santykiai gali sustiprinti tėvų ir ikimokyklinio ugdymo institucijos bendradarbiavimą tarpusavyje, o tai labai svarbu, siekiant bendrų tikslų. Visa tai ir pagrindžia pasirinktos temos aktualumą.

Tyrimo problema: kaip vyksta bendradarbiavimas tarp pedagogų ir tėvųugdant autizmo spektro sutrikimą turinčius vaikus.

Tyrimo objektas - pedagogų ir tėvų bendradarbiavimas.

Tyrimo tikslas - išanalizuoti pedagogų ir tèvų bendradarbiavimą ugdant autizmo spektro sutrikimą turinčius vaikus.

Tyrimo uždaviniai:

1. Teoriškai atskleisti pedagogų ir tėvų bendradarbiavimo ypatumus ugdant autizmo spektro sutrikimą turinčius vaikus.

2. Empiriškai nustatyti pedagogų ir tèvų bendradarbiavimo formas ir metodus ugdant autizmo spektro sutrikimą turinčius vaikus. 
Tyrimo metodai: mokslinès literatūros analizè, struktūrizuotas interviu, kokybinè tyrimo rezultatų analizè.

\section{Pedagogụ ir tėvų bendradarbiavimo ugdant autizmo spektro sutrikimą turinčius vaikus teorinè analizè}

\subsection{Autizmo spektro sutrikimo apibrèžtis, priežastys ir būdingiausi požymiai}

Autizmo sąvoką kilusi iš graikų kalbos, žodžio autos, pirmą kartą paminèjo ir aprašè psichiatras Bleuleris Eugenas 1911 metais. Analizuodamas ir aprašydamas autizmo spektro sutrikimą jis nurodè, kad autizmo spektro sutrikimą turintis žmogus yra uždaras, turi savą "pasaulį", išgyvenimus ir i juos dažnai nugrimzdantis. Ankščiau autizmo sąvoka nebuvo vartojama, vietoje jos buvo vartojama šizofrenijos sąvoka. Tuo metu toks sąvoku vartojimas leido suvokti du skirtingus sutrikimus (Klimavičius, 2015). Ankščiau buvo manoma, kad autizmo spektro sutrikimasyra pakankamai sunkus emocinis sutrikimas arba schizofrenija. Baron-Cohen (2011) teigimu turètume sujungti klasikini autizmą ir autizmą deranti su pakankamai aukštu intelektu bei Aspergerio sindromu, kad gautume autizmo spektrą. Mickevičienè, Šinkariova, Perminas (2009) teigimu, autizmo spektro sutrikimas yra pakankamai plataus spektro sutrikimas, kuri sukelia biologiniai, genetiniai, organiniai veiksniai. Nèra aišku, kokios yra autizmo spektro sutrikimo pasireiškimo priežastys. Autizmo spektro sutrikimo diagnozė nustatoma jau ankstyvajame amžiuje. Autizmo diagnozė nustatoma šešiems iš tūkstančio vaikų, dažniausiai nustatomaberniukams. Šiai dienai tampa aišku, kad tam tikra genų kombinacija gali ittakoti autizmo spektro sutrikimo atsiradimą. Mokslininkai atsakymų ieško nuolatos, spejjimų daug, bet klausimų dar daugiau (Pilkauskienè, 2008). Kita vertus, autizmo spektro sutrikimas įtakoja ir tai, kad vaikas nustoja ịgti ịgūdžius būdingus jo raidai arba praranda jau turimus ịgūžius. Baron-Cohen (2011) teigè, kad vaikai turintys autizmo spektro sutrikimą susidomi neịprastais daiktais, vèlai ima kalbèti, prasti turimi socialiniai gebèjimai, turi ribotą vaizduotę, būdingas užsisklendimas savyje. Kiti vaikai, turintys autizmo spektro sutrikimą - geba bendrauti, bet nepalaiko akių kontakto. Pastebimi ir tokie požymiai: vaikai turi puikius gebejjimus skaičiavimo srityje, geba tiksliai atkartoti lẻktuvų tvarkaraščius, traukinių tvarkaraščius, greitai juos ịsimena. Labai greitai išmoksta užsienio kalbas, perpranta gramatiką, ịsimena žodžius, nors iki tol jam sunkiai sekèsi pačiam kalbèti, komunikuoti (Baron-Cohen, 2011).Vaikai, turintys autizmo spektro sutrikimą, gali savo išvaizda niekuo nesiskirti nuo kitų vaikų, tačiau dažnai žmogui žiūrint iš šalies jie atrodo keisti: užsidarę, grubūs, nebendraujantys su vaikais ar jų aplinkoje esančiais žmonèmis. Kontaktas su aplinkiniais yra ribotas, sudètingas. Autizmo spektro sutrikimas riboja bendravimą, komunikavimą ịūdžių ịsisavinimą. Pasak Ivoškuvienè, Urbutytès (2008), "autizmo spektro sutrikimą turinčiais asmenimis labai domimasi, tačiau iki šiol lieka daug neaiškumų.Pagrindiniai autizmo spektro požymiai yra skiriami šie: vaikas negeba atjausti; suvokti kitų emocijų; jausmų; elgesio; atrodo užsidarę savyje; nesiekia draugystės su kitais bendraamžiais; pasireiškiantis abejingumas; empatija;itin sunku suprasti verbalini ir neverbalini bendravimą. Bendravimo procese nenaudojaakių kontakto, savo veido išraiškos, gestų kalbos ir kūno kalbos, susiduriama su veiklos atlikimo problema, vaikas dažnai ploja rankomis, siūbuoja, greitai sukasi vietoje, jautriai reaguoja ị triukšmą, kvapus, prisilietimus, vaizdinius dirgiklius.

Nelieka abejonių, kad, autizmo spektro sutrikimas yra vienas iš sudėtingesnių raidos sutrikimų egzistuojančių pasaulyje. Šio sutrikimo paplitimas kas dieną didèja. Pastebima, kad ịvairiuose informaciniuose šaltiniuose pradedama vartoti sąvoka - "autizmo epidemija". Visi skaičiai parodantys, kiek pasaulyje yra vaikų turinčių autizmo spektro sutrikimą nėra labai tikslūs, kadangi ne visiems yra patvirtintas šis sutrikimas. Galima apytiksliai suskaičiuoti, kiek iš viso yra vaikų, kuriems nustatyta autizmo spektro sutrikimo diagnozè, o kiek dar nenustatyta. Visa tai atskleidžia dar vieną problemą, kurią reikètų išspręsti, kadangi kuo ankščiau vaikui nustatoma diagnozè, tuo ankščiau jam galima padèti (Nacionalinè švietimo agentūra, 2016).

Taigi, autizmo spektro sutrikimas - jvairiapusis raidos sutrikimas, išryškëjantis ankstyvajame amžiuje ar tik vaikui paaugus. Jo atsiradima gali ịtakoti genetika, dirvožemio ar oro užterštumas cheminemis medžiagomis, tam tikru medžiagu organizme stoka, maisto perdirbimas ir kt. Autizmo sutrikimas pasireiškia kalbos ir bendravimo, elgesio sunkumais, pojūčiu, mąstymo, vaizduotès 
sutrikimais, socialiniu gebejjimu ir interesu stoka. Šis sutrikimas veikia visq vaiko veikla - verbalinę ir neverbalinę komunikacija, socialinès squveikos su kitais asmeinis kokybę. Neapibrëžtas sutrikimo gydymas ar jos eigos švelninimas reikalingas tam, kad vaikas, o paskui žmogus galètu kiek įmanoma socialiai pilnavertiškai gyventi.

\subsection{Bendradarbiavimo ypatumai ugdant vaikus, turinčius autizmo spektro sutrikimą}

Francescon Cittolin (2018) teigimu, bendradarbiavimas - platus bendradarbiavimo tinklas. Viena iš sẻkmès formų. İrankis, padedantis siekti užsibrèžtų, bendrų tikslų.Šavrina, Grundey, Berzina (2008) nuomone, bendradarbiavimas vyksta tik tada, kai du ar daugiau asmenų siekia bendro tikslo ar tikslų. Taigi, apskritai bendradarbiavimas reiškia, bet kokį bendro pobūdžio veiklą tarp žmonių.

Bendradarbiavimo nuostatas atrandame įtvirtintas Lietuvos Respublikos švietimo įstatyme ir švietimo ministro įsakymuose ir kituose Lietuvos Respublikos išleistuose teisès aktuose. Reikètų pabrèžti, kad Lietuvoje yra skatinama bendradarbiauti, siekiant vaiko gerovès. Šiuose teisès aktuose ịtvirtintos įvairios nuostatos nuo to, kokių krypčių reikia laikytis dirbant su vaiku iki to, kaip turi atrodyti bendras specialistų darbas. Taigi, kas skatina bendradarbiavimą? Bendradarbiavimą skatina tam tikri veiksniai: aktyvus tėvų dalyvavimas, vieningumas komandiniame darbe, aktyvus vaiko dalyvavimo skatinimas, ugdytojų demesys vaikui ir jo problemoms, drąsa kreipiantis pagalbos i specialistus, kitoks tėvų požiūris ị vaiko turimus sunkumus, specialistų įsitraukimas, puikiai veikiantis partnerystės tinklas, atsakingas požiūris ị vaiko sunkumus, operatyvus reagavimas i juos, specialistų aukšta kvalifikacija, gebejimas dirbti komandoje, tarpusavio funkcijų tinkamas paskirstymas komandoje, nuolatinis komandinių ryšių palaikymas (Kairienè, 2010).Visa tai priartina bendradarbiaujančias puses prie bendrų tikslų igyvendinimo, teisingo tarpusavio ryšio kūrimo, partnerystės užtikrinimo. Tik bendra veikla, tarpusavio bendradarbiavimas gali duoti norimų rezultatų. Todėl, siekiant vaiko gerovės yra būtinas bendradarbiavimas tarp pedagogų, specialistu ir šeimos (Burvyte, 2019).Vaiko ugdymosi poreikių patenkinimas be specialistų ịsikišimo ir bendradarbiavimo nèra įmanomas. Bendradarbiavimą skatina suvokimas ir noras padèti vaikui. Dažnai vaiko vaiko sutrikimus pastebi ne tèvai, bet pedagogas. Pedagogas, kiekvieną rytą dirbdamas su ugdytiniais, perteikia jiems žinias, formuoja ịvairias kompetencijas, bendrauja su jais, įtraukia juos $\mathfrak{i}$ ugdymo proceso eigą. Pedagogas taip pat pastebi ir ugdytinių ugdymosi pasiekimus ar galimybes, ir supranta, kad ne visų ugdytinių ugdymosi galimybès yra vienodos. Suvokdamas, kad vaikas turi sutrikimų, pedagogas gali kreiptis pagalbos. Šiuo atveju pedagogas ieško pagalbos savo ugdymo ịstaigoje ar kreipiasi ị kitas institucijas. Ivvairių specialistų ir kompetentingų pedagogų komisija gali duoti teigiamų rezultatų analizuojant ir vertinant vaiko ugdymosi galimybes, poreikius (Švietimo metodinès rekomendacijos, 2010). Pedagogai pasirenka ịvairias bendradarbiavimo su ugdytiniu tèvais formas: tėvų susirinkimai, tėvų švietimas, išvykos, individualus darbas, šventès, susirašinèjimas, renginiai, specialistų konsultacijos (Gustaitienè, Širiakovienè, 2020). Tenkinant vaiko ugdymosi poreikius ugdymo įstaigoje dirbantys pedagogas ir kiti specialistai suburiami ị komandą. Vieno vienintelio ir visiems pritaikomo bendradarbiavimo modelio - nèra. Kiekvienos ugdymo ịstaigos, vaikų poreikių ir galimybių skirtumai igalina sukurti ne vieną bendradarbiavimo modelį ar jo struktūrą (Miltenienè, 2005). Bendradarbiavimo kryptys gali būti dvi: vidiné ir išorinė. Vidinè kryptis apima visus skirtingos specializacijos žmones, kurie dirba ugdymo įstaigoje, o išorinė kryptis apima įvairius specialistus, dirbančius skirtingose institucijose. Sių specialistų bendradarbiavimas tarpusavyje ir duoda pakankamai gerus rezultatus ateityje, siekiant vaiko ugdymosi poreikių patenkinimo (Vaicekauskienė, 2003). Kairienè (2010) analizuodama komandos narių bendradarbiavimą nurodo, kad bendradarbiaujant su vaiko šeima specialistai dažniausiai naudoja šias bendradarbiavimo formas: konsultaciją ir tiesiogini bendravimą su vaiku. Jos metu specialistai išsamiai paaiškina susiklosčiusią situaciją, atsako ị tèvams rūpimus klausimus, o klausimų būna labai daug ir įvairių. Informacijos pateikimas tèvams apima šiuos būdus: pademonstruoja arba išsamiai paaiškina, kokie veiksmai bus atliekami vienu ar kitu momentu, pasiūloma tèvams perskaityti informacijos šaltinius, kurie supažindina tėvus su susiklosčiusią situacija. Specialistai taip pat vertinimo metu supažindina tèvus su gautais vertinimo rezultatais, nurodo, vaiko problemą. Tẻvams pateikiama informacija susijusi su 
vaiko raida, teikiamos ịvairios suformuotos rekomendacijos, kurios taikomos ne tik ugdymo ịstaigoje, bet ir vaiko namuose. Specialistai nurodo, kad tam, kad pagalba vaikui būtų teikiama yra reikalingas tèvų noras bendradarbiauti, problemos suvokimas ir supratimas, kad problemą reikia spręsti, aktyvus dalyvavimas ugdymo procese, bendri lūkesčiai vaiko atžvilgiu. Specialistų bendradarbiavimas remiasi modeliu, kuris nukreiptas i informacijos keitimąsi vienas su kitu, konsultacijas, problemos ar problemų aptarimą, vaiko ịūdžių formavimą, tęstinumą. Kalyva (2013), analizuodama tèvų, kurių vaikai turi autizmo spektro sutrikimą, pabrěžia, kad specialistai ir tèvai turi bendradarbiauti tarpusavyje, norèdami suteikti visapusiųką pagalbą vaikui. Tẻvai traktuojami kaip partneriai, konsultantai, vaiko globejjai ir rèmèjai. Tèvai, bandydami padèti, dažnai siekia dirbti kartu su specialistais ir jų vaikai dažniausiai ịveikia sunkumus, todèl, svarbu padidinti tėvų savarankiškumą ir skatinti jų ịsitraukimą i sprendimų prièmimą.Jungtinèje Karalystëje vaikui pagalba teikiama taikant intervencijas ir tėvų mokymo programą, ì kurią įtraukiamos vaiko elgesio analizès, vaiko draugų ratas, vaiko kalba, kasdienio gyvenimo igūdžių ugdymas, ankstyvojo ugdymo programa, speciali vaiko adaptacijos programa, ìvairios terapijos, susijusios su muzika, paveikslėlių sistema, autizmo spektro sutrikimą turinčių vaikų ugdymo programa. Jungtinèje Karalystejje pedagogai intensyviai ir kruopščiai ịsigilina ị kiekvieną problemą ir bando ịveikti visus sunkumus kartu priimant $\mathfrak{i}$ komandą: vaiko tèvus ir kitus specialistus. Tačiau, Jungtinèje Karalystėje autizmo spektro sutrikimą turinčių vaikų pagalbos teikimas priklauso ir nuo ugdytinio intelekto. Ugdymo forma skiriama atsižvelgus ị švietimo įstaigos specialistus, jų patirtị nei nuostatas. Ugdymo metu iškylančios problemos ir neaiškumai sprendžiami siunčiant vaiką vertinimui. Visa ugdymo įstaiga skatinama ugdymo aplinką pritaikyti pagal ugdytinio poreikius. Teikiant pagalbą ar ugdant, autizmo sutrikimą turintį vaiką, Jungtinejje Karalysteje yra taikomos tokios nuostatos:

- Reikia suprasti autizmo spektro sutrikimui būdingas savybes;

- Reikia turèti žinių apie autizmo spektro sutrikimą;

- Gebèti atpažinti autizmo spektro sutrikimą ankstyvoje fazėje ir taikyti intervenciją;

- Reikia aktyviai bendradarbiauti su tèvais, teikti jiems pagalbą sudarant pagalbos šeimai planą;

- I ugdymo procesą įtraukti vaiką, atsižvelgiant ị jo nuomonę;

- Reikia bendradarbiauti su kitomis institucijomis padėsiančiomis igyvendinti intervenciją (Skučaitè, Karmazè, 2011).

Danijoje pagalbą teikia Nacionalinis autizmo centras, kuris priklauso socialinių reikalų ministerijai. Šis centras užtikrina kokybišką pagalbą asmenims, kuriems pripažintas autizmo spektro sutrikimas. Jis renka informaciją apie autizmo spektro sutrikimą arba ją kuria, remiasi ir kitų valstybių patirtimi, stebi tyrimuose užfiksuotus duomenis, atnaujina, pateikia ịvairius straipsnius, projektus, bendradarbiauja su kitomis užsienio ar Danijos valstybinėmis institucijomis, organizacijomis, kaupia duomenų bazèse ịvairią medžiagą, literatūrą, šaltinius, leidžia: brošiūras, lankstinukus, vaizdo medžiagą, knygas autizmo spektro sutrikimo tema, rengia ir organizuoja paskaitas tèvams apie autizmo spektro sutrikimą. Manoma, kad labai mažai dèmesio skiriama autizmo spektro diagnozès tikslinimui, o didžiausias dèmesys skiriamas ugdymo strategijų paieškoms. Autizmo spektro sutrikimą turintys vaikai Danijoje dažniausiai ugdomi specializuotose ugdymo institucijose ir jam tenka vieno specialisto priežiūra. Nežiūrint ị šią problemą, Danijoje atrandama daug gerų patirčių, ugdymo programų, padedančių suvokti, kaip dirbti su autizmo spektro sutrikimą turinčiais vaikais (Ališauskas, Ališauskienė, Gerulaitis, Kaffemanienè, Melienè, Miltenienė, 2011). Taigi, svarbiausias pedagogui ugdančiam autizmo spektro sutrikimą turinčius vaikus uždavinys - žinių, bendravimo igūdžių, gyvenimo ịūdžiu formavimas vaikams. Kiekvienam vaikui turinčiam autizmo spektro sutrikimą turi būti sudaroma ugdymo programa, kuri orientuota ị aplinkos kūrimą, kalbos ugdymą, bendravimo skatinimui, tikslų nustatymą ir sekimą. Pastebima, kad autizmo spektro sutrikimą turintys vaikai bendraudami su gyvūnais ar dalyvaudami veiklose su jais jaučiasi labai gerai, gyvūnai vaikams padeda ivveikti autizmo spektro sutrikimo simptomus, pvz., geriau vaikai miega, tampa ramesni, labiau susikaupia, pradeda bendrauti. Manoma, kad pedagogai ir specialieji pedagogai daro didžiausią ịtaką bendradarbiavimo efektyvumui ugdant autizmo spektro sutrikimą turinčius vaikus. Trūksta tyrimų, susijusių su pedagogų, tėvų, specialiųjų pedagogų bendradarbiavimu. Trūksta ir jų požiūriu analizès apie bendradarbiavimą, tenkinant vaiko ugdymo poreikius (Miltenienè, 2004). Pedagogai, vaiko tėvai 
ir specialistai daro didžiausią itaką bendradarbiavimo efektyvumui ugdant autizmo spektro sutrikimą turinčius vaikus. Specialistai yra svarbūs, bet svarbūs šiuo atveju yra ir vaiko tèvai. Dažnai pedagogas ir specialistas tėvams paskiria vykdytojų vaidmeni arba įvardija tai - partneryste. Reikia tèvus įtraukti ne tik ị ugdymo procesą, bet ir ugdymo įstaigos bendruomenès gyvenimą, jeigu informaciją perduota bus iš ugdymo įstaigos tèvams, siekiamo bendradarbiavimo čia nebus, nes tèvai bus tik ịpareigojimu vykdytojai, pareiškiantys savo prieštaravimus savo lūkesčius (Miltenienė, 2004). Europoje, švietimą reglamentuojančiose dokumentuose, bendradarbiavimas ugdymo procese laikomas vertybe, siekiamybe, priemone tam tikriems tikslams pasiekti. Bendradarbiavimas tarpusavyje suteikia galimybę pakeisti ugdymo dalyvių ịsitikinimus, nuostatas, skatina tarpusavio informacijos dalinimąsi, naujų žinių ịsisavinimą (Miltenienė, 2005).

Apibendrinant galima teigti, kad bendradarbiavimas yra vertybe, kuri laikoma, kaip priemone tam tikriems tikslams pasiekti. Vaiko ugdymosi poreikiu patenkinimas be specialistu isikišimo ir bendradarbiavimo néra i̇manomas, todèl tèvu, pedagogu ir specialistu bendradarbiavimas yra labai svarbus ir reikalingas. Bendravimas laikytinas vienas iš pagrindinių žmogaus gebejjimu, vertybiu, kurios turètu büti vertinamos.

\section{Pedagogų ir tẻvų bendradarbiavimo ugdant autizmo spektro sutrikimą turinčius vaikus tyrimo rezultatų analizè}

\subsection{Tyrimo metodika}

Tyrimo proceso dalyviai.Tyrimas buvo atliktas 2021 metais. Siekiant ištirtipedagogų ir tèvų bendradarbiavimą ugdant autizmo spektro sutrikimą turinčius vaikus buvo parengtas tyrimo instrumentas: interviu klausimynas pedagogams. Remiantis sudarytu klausimynu buvo apklausti šeši ikimokyklinio ugdymo pedagogai, ugdantys autizmo spektro sutrikimą turinčius vaikus. Tyrimo dalyviai buvo atrenkami remiantis vienu iš netikimybinès atrankos tipu, t.y patogiają atranka. Buvo pasirenkami tie generalinès aibès vienetai, kurie buvo lengvai prieinami. Tyrime dalyvavusiems informantams yra suteikiama koduotè. Tyrime dalyvavę informantai pažymèti raidèmis: A, B, C, D, E ir F.

Atliekant tyrimą buvo pasirinkti šie tyrimo metodai: mokslinès literatūros analizè, struktūrizuotas interviu, kokybinè tyrimo rezultatu analizè. Remiantis parengtu kokybinio tyrimo klausimynu, buvo renkami tyrimo duomenys.Tiriamiesiems pateikti atviri klausimai suteikè galimybę suvokti pedagogų ir tėvų bendradarbiavimo ypatumus, ugdant autizmo spektro sutrikimą turinčius vaikus. Gauti tyrimo rezultatai išanalizuoti ir susisteminti, naudojant Microsoft Office kompiuterine programa. Tyrimo rezultatų susisteminimui buvo taikomas kokybinès tyrimo rezultatų analizès metodas, kategorijos ir subkategorijos sudarytos atsižvelgiant ị teorinę darbo analizę, informantų pateikti atsakymai pagrịsti ịvairių autorių nuomonėmis ir teiginiais.

Tyrimo etika. Remiantis konfidencialumo, pagarbos, anonimiškumo principais, konfidenciali tyrimo dalyvių informacija nèra ir nebus atskleidžiama.

\section{Pedagogų ir tẻvų bendradarbiavimo ugdant autizmo spektro sutrikimą turinčius vaikus tyrimo rezultatų analiż}

Tyrimo metu informantų buvo prašoma nurodyti vaiko su autizmo spektro sutrikimu, kuris yra ugdomas jų grupejje, būdingiausius bruožus.Atsakymai, gauti iš pedagogų interviu metu, apibendrinti ir pateikti 1 lentelèje. Vieno ir konkretaus autizmo spektro sutrikimo bruožo, kaip rodiklio nèra, dažniausiai pasireiškia keletas jų. Daugumos informantų (4) teigimu, vaiko autizmo spektro sutrikimu, kuris yra grupèje, būdingiausi bruožai pasireiškia socialinès squveikos sutrikimu srityje. Informantų atsakymai iš dalies sutampa su Ivoškuvienès, Urbutytès (2008) tyrimo rezultatais. Autorès įvardija šiuos pagrindinius bruožus, būdingus autizmo spektro sutrikimą turintiems vaikams: domejjimąsi savo rankų pirštais, nesidomèjimą žaislais, nuolatinį supimąsi, akių kontakto vengimą ir pan. Pasak Zvicevičienès, Aleksienès (2008), autizmo spektro sutrikimas yra labai sudètingas raidos sutrikimas, kuris pasireiškia verbalinio ir neverbalinio bendravimo sutrikimais. Šiai autorių nuomonei pritaria ir 
dalis informantų (2), kurie nurodè, kad vaiko, turinčio autizmo spektro sutrikimą, esančio grupèje, būdingiausi bruožai apima ir verbalinès ir neverbalinès kalbos sutrikimus.

1 lentelè. Vaiko, ugdomo grupèje su autizmo spektro sutrikimu, būdingiausi bruožai

\begin{tabular}{|c|c|c|}
\hline Kategorija & Subkategorija & Pagrindžiantys teiginiai \\
\hline \multirow[t]{4}{*}{$\begin{array}{l}\text { Bruožai, būdingi vaikams, } \\
\text { kuriems diagnozuotas } \\
\text { autizmo spektro sutrikimas }\end{array}$} & $\begin{array}{l}\text { Socialinės sąveikos } \\
\text { sutrikimai }\end{array}$ & $\begin{array}{l}\text { „...Nenoras bendrauti su grupès draugais...“(A); } \\
\text { „...Užsidarymas savyje, abejingumas...“(C); } \\
\text { „...Akių kontakto vengimas...“(A, C, E, B); }\end{array}$ \\
\hline & $\begin{array}{l}\text { Verbalinès ir } \\
\text { neverbalinès kalbos } \\
\text { sutrikimai }\end{array}$ & $\begin{array}{l}\text { „...Sakytinès kalbos vėlavimas, girdètu frazių nuolatinis } \\
\text { kartojimas arba atkartojimas...“(A); } \\
\text { „...Vaikui nepavyksta atkartoti gestų, palaikyti pokalbị. Jie } \\
\text { sunkiai bendrauja...“(B); }\end{array}$ \\
\hline & $\begin{array}{l}\text { Padidintas jautrumas } \\
\text { stimulams }\end{array}$ & $\begin{array}{l}\text { „...Jautrumas pašaliniams garsams arba triukšmui..." (D); } \\
\text { „...Užsidengia akis nuo ji blaškančios šviesos, skleidžia garsą, } \\
\text { siekdamas pašalinti ji blaškančius faktorius. ..." (B); }\end{array}$ \\
\hline & Elgesio sunkumai & $\begin{array}{l}\text { „...Vengia fizinio kontakto...“( }(\mathrm{D}) \text {; } \\
, \ldots \text { Būdingas nervingumas, agresija...“ (E). }\end{array}$ \\
\hline
\end{tabular}

Šaltinis: sudarytas autorių remiantis atlikto tyrimo duomenimis, 2021

Informantų nuomonę patvirtina ir Grigènaitè (2020), kuri teigia, kad autizmo spektro sutrikimą turintys vaikai pasižymi ịvairiais požymiais, vienas iš jų yra komunikacijos sutrikimo problemos. Anot dalies informantų (2), vaiko su autizmo spektro sutrikimu, ugdomo grupèje, būdingiausiems bruožams priskiriami ir pojūčiu sutrikimai, t.y padidintas jautrumas aplinkos dirgikliams. Pasak Ulevičiūtès, Gaigalienès (2008), daugelio autizmui priskirtų sutrikimų pašalinti ar išgydyti nèra galimybès, tačiau atsižvelgiant ị pojūčių problemas, ypatumus, galima rasti tam tikrų sunkumų ịveikimo būdus, padèsiančius vaikui tapti bent kiek nepriklausomam nuo kitų žmonių, savarankiškesniam. Anot Saveikienès (2018), autizmo spektro sutrikimui yra būdingas elgesio sutrikimas. Pasak autorès, autizmo spektro sutrikimo simptomatika lemia tam tikrus raidos nuokrypius, kurie apima daug veiksnių ir kurie trunka visą gyvenimą. Vienas iš tokių ir yra elgesio sunkumai. Šiai nuomonei iš dalies pritaria ir informantai (2), kurie teigia, kad vaiko su autizmo spektro sutrikimu, ugdomo jų grupejje, būdingiausi bruožai apima ir elgesio sunkumus.

Apibendrinant informanty atsakymus, galima teigti, kad vaiko su autizmo spektro sutrikimu, ugdomo grupeje, büdingiausi bruožai yra: socialinès sqveikos sutrikimai, verbalinès ir neverbalinès kalbos sutrikimai, padidintas jautrumas stimulams, elgesio sunkumai.

Tyrimo metu norèta išsiaiškinti, kokios pagalbos teikimo rūšys naudojamos, bendradarbiaujant su autizmo spektro sutrikimą turinčių vaikų tèvais (žr. 2 lentelè).

2 lentelè. Pagalbos rūšių teikimas, bendradarbiaujant su autizmo spektro sutrikimą turinčių vaikų tėvais

\begin{tabular}{|c|c|c|}
\hline Kategorija & Subkategorija & Pagrindžiantys teiginiai \\
\hline \multirow[t]{4}{*}{$\begin{array}{l}\text { Pagalbos teikimo } \\
\text { rūšys, } \\
\text { bendradarbiaujant } \\
\text { su autizmo } \\
\text { spektro sutrikimą } \\
\text { turinčių vaikų } \\
\text { tėvais }\end{array}$} & Tėvų švietimas & 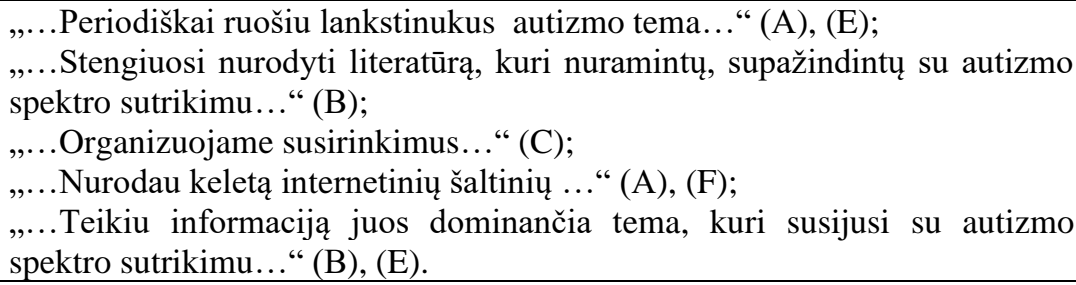 \\
\hline & $\begin{array}{l}\text { Kompleksinè } \\
\text { pagalba arba } \\
\text { komandinis darbas }\end{array}$ & $\begin{array}{l}\text { „...Kreipiuosi i vaiko gerovės komisiją dėl vaiko specialiujų poreikių } \\
\text { patenkinimo..." }(\text { E); } \\
\text { „...Padedu suburiant vaiko gerovės komisijos narius bendram darbui, } \\
\text { siekiant visapusiško vaiko poreikių patenkinimo..." (F). }\end{array}$ \\
\hline & $\begin{array}{l}\text { Nukreipimas pas } \\
\text { specialistus }\end{array}$ & $\begin{array}{l}\text { „... Rekomenduoju tėvams kreiptis i šeimos konsultantus, psichologus, } \\
\text { ịvairius terapeutus..." }(\mathrm{C}) \text {; } \\
\text { „...Visada nukreipiu link specialisto, jeigu matau, kad problema gilesne ir } \\
\text { reikalingas kitos kvalifikacijos žmogaus įsikišimas..."(D). }\end{array}$ \\
\hline & $\begin{array}{l}\text { Tyrimų } \\
\text { organizavimas }\end{array}$ & $\begin{array}{l}\text { „...Atliekami tyrimai, kurie leidžia suvokti, kokios pagalbos tèvai tikisi, } \\
\text { kokia ji reikalinga..." }(\mathrm{C}) \text {. }\end{array}$ \\
\hline
\end{tabular}

Šaltinis: sudarytas autorių, remiantis atlikto tyrimo duomenimis, 2021 
Didžioji dalis informantų (5) pagalbos teikimui igyvendinti pasirenka tėvu švietima. Tyrimo rezultatai atliepia Leliūgienès, Simanavičiūtės (2010) mintis: tėvų švietimas remiasi sẻkminga vaiko socializacijos prielaida. Autorès nurodo, kad tėvų švietimas garantuoja jų pilnavertį dalyvavimą ugdymo procese, nes šiuo būdu yra sudaromos sąlygos įgyti reikiamų žinių. Daugumainformantų (4) akcentuoja tèvų nukreipima pas specialistus. Jų atsakymai sutampa su Samsonienès, Bencion Malkin, Kairio, Juozulyno (2017) nuomone: specialistai daro didelę įtaką šeimai, jos gyvenimui ir gerovei. Kita dalis informantų (2) nurodo padedantys tèvams sutelkti komandą vaiko specialiujų poreikių patenkinimui, problemoms spręsti, nukreipia i Vaiko gerovès komisiją. Anot Baraldsnès, Vaškienès (2013), Vaiko gerovès komisijai pavesta ịvairių funkcijų, kurios padeda išspręsti ịvairias iškilusias problemas, susijusias su vaiko specialiujų ugdymosi poreikių patenkinimu. Vienas informantas (1) pagalbos teikimą sieja su tyrimų organizavimu. Šių tyrimų esmé, anot informanto, išsiaiškinti,kokios pagalbos tèvai tikisi ir norètu sulaukti iš pedagogo.

Apibendrinant gautus tyrimo rezultatus, galima teigti, kad pedagogai stengiasi dèl vaiko gerovès, bendram darbui pakviesdami įvairius specialistus. Tokiu būdu stengiamasi surasti efektyviausius pagalbos teikimo būdus ir formas.Dažniausiai teikiama pagalbos rūšis yra tèvu švietimas, kurio metuteikiama tèvams ìvairi informacija apie vaiko raidos ypatumus, ugdymosi pasiekimus, psichologinès pagalbos šaltinius.Kitos naudojamos pagalbos formos, bendradarbiaujant su autizmo spektro sutrikima turinčiu vaiku tèvais, yra šios: komandinis darbas, nukreipimas pas specialistus, tyrimu organizavimas. Pedagogines pagalbos teikimas tèvams pagerina tèvu psichologine būsena, padeda suvokti bendradarbiavimo proceso esmę bei nauda, siekiant patenkinti vaiko poreikius ir užtikrinti jo gerovę.

Interviu metu norèta atskleisti, kokias bendradarbiavimo formas pedagogai naudoja, itraukdami tèvus, auginančius autizmo spektro sutrikimą turinčius vaikus, ị ugdymo procesą (žr. 3 lentelè).

3 lentelè. Bendradarbiavimo formų naudojimas, įtraukiant autizmo spektro sutrikimą turinčių vaikų tèvus ị ugdymo procesa

\begin{tabular}{|c|c|c|}
\hline Kategorija & Subkategorija & Pagrindžiantys teiginiai \\
\hline \multirow{4}{*}{$\begin{array}{l}\text { Bendradarbiavimo } \\
\text { formų } \\
\text { naudojimas, } \\
\text { įtraukiant autizmo } \\
\text { spektro sutrikimą } \\
\text { turinčių vaikų } \\
\text { tèvus į ugdymo } \\
\text { procesą }\end{array}$} & $\begin{array}{l}\text { Individualūs pokalbiai ir } \\
\text { susitikimai }\end{array}$ & $\begin{array}{l}\text { „...Individualūs pokalbiai...“(A), (B), (D), (E); } \\
\text { „...Pokalbis telefonu...“(D); } \\
\text {,...Individualūs susitikimai...“ (A); } \\
\text {,...Supažindinu tèvus su vaiko pasiekimais, elgesiu...“ (B), (C), } \\
\text { (F).... }\end{array}$ \\
\hline & Susirinkimai & „...Susirinkimai...“(A), (F); \\
\hline & $\begin{array}{l}\text { Bendri renginiai, šventès ir } \\
\text { išvykos }\end{array}$ & $\begin{array}{l}\text { „...Bendros šventės...“(C); } \\
\text {,...Kviečiu i bendruomenès organizuojamus renginius...“(A), (B), } \\
\text { (D), (E), (C); } \\
\text {...Ivairios išvykos...“ (F). }\end{array}$ \\
\hline & Ugdomosios veiklos & $\begin{array}{l}\text { „„...Organizuojame įvairiomis temomis atviras ugdomąsias } \\
\text { veiklas..." (B), (C), (F). }\end{array}$ \\
\hline
\end{tabular}

Šaltinis: sudarytas autorių, remiantis atlikto tyrimo duomenimis, 2021

Turẻdami daugiau žinių, praktinių ịgūdžių, pedagogai gali bendradarbiaudami tas žinias perteikti tèvams. Visi informantai (6) nurodo naudojantys šias bendradarbiavimo su tèvais formas: bendrus renginius, šventes ir išvykas, kurios, anot Kaffemanienès ir Žukaitès (2008), taikomos norint suplanuoti, individualizuoti ar sumodeliuoti specialiujų ugdymosi poreikių vaikų ugdymą. Remiantis gautais tyrimų rezultatais, galima teigti, kad didžioji dalis informantų (5) tėvų ịtraukimui ị ugdymo procesą renkasi individualius pokalbius ir susitikimus, kurie, pasak Miltenienès (2005), yra dažniausiai pedagogų pasirenkama bendradarbiavimui su tėvais forma. Anot Vijūnaitès ir Slušnienès (2018), individualios bendradarbiavimo su tèvais formos, tai tokios formos, kurios taikomos vis dažniau, atsižvelgiant į šiandienini gyvenimą, atsirandančias naujoves ir šių naujovių pritaikymo galimybes. Pasak Griciūnaitės (2016), ugdymo ịstaiga, norėdama teikti kokybiškas paslaugas, turi identifikuoti tėvų poreikius, lūkesčius, patirtį, vertybes bei ịtraukti tèvus ị ugdomąsias veiklas, siekiant efektyvios partnerystès užtikrinimo. Šiai nuomonei iš dalies pritaria ir pusè tyrime dalyvavusių informantų (3), kurie nurodè, kad siekiant efektyvaus bendradarbiavimo su tėvais, auginančiais autizmo spektro 
sutrikimą turinčius vaikus, ị ugdymo procesą ịtraukti juos yra būtina. Pasak Gelžinytės, Bagdono (2016), susirinkimai yra viena iš sėkmingo bendradarbiavimo su tèvais formų. Šiai nuomonei pritaria ir informantai (2).

Apibendrinant tyrimo rezultatus, galima teigti, kad tèvu ịtraukimui ị ugdymo procesa dažniausiai naudojamos bendradarbiavimo formos yra šios: individualūs pokalbiai ir susitikimai, bendri renginiai, šventès ir išvykos, šiek tiek rečiau - ugdomosios veiklos ir susirinkimai.

Tyrimo metu siekta išsiaiškinti sėkmès veiksnius, galinčius pagerinti bendradarbiavimą su tèvais ugdant vaikus, turinčius autizmo spektro sutrikimą. Gauti tyrimo rezultatai apibendrinti ir pateikti 4 lentelèje (žr. 4 lentelè).

4 lentelè. Sėkmės veiksniai, galintys pagerinti bendradarbiavimą su tėvais ugdant vaikus, turinčius autizmo spektro sutrikima

\begin{tabular}{|c|c|c|}
\hline Kategorija & Subkategorija & Pagrindžiantys teiginiai \\
\hline \multirow{4}{*}{$\begin{array}{l}\text { Sėkmės veiksniai, } \\
\text { galintys pagerinti } \\
\text { bendradarbiavimą } \\
\text { su tėvais ugdant } \\
\text { vaikus, turinčius } \\
\text { autizmo spektro } \\
\text { sutrikimą }\end{array}$} & $\begin{array}{l}\text { Pasitikèjimo ugdymo } \\
\text { istaiga skatinimas }\end{array}$ & „,...Skatinti pasitikèjimą ugdymo įstaiga...“(B); \\
\hline & $\begin{array}{l}\text { Teigiamos atmosferos } \\
\text { gerinimas }\end{array}$ & $\begin{array}{l}\text { „...Stengtis grupès aplinkoje ir ugdymo įstaigoje sudaryti tokią } \\
\text { aplinką, kurioje nebūtų formalumų, suvaržymų..."(A); }\end{array}$ \\
\hline & $\begin{array}{l}\text { Informacijos skleidimo } \\
\text { gerinimas }\end{array}$ & $\begin{array}{l}\text { „... Organizuoti atviras veiklas... pokalbius, sisteminti informaciją } \\
\text { apie vaiko pažangą, igūdžius, o su gautais rezultatais supažindinti } \\
\text { tėvus, vykdyti tėvų konsultacijas, organizuoti bendrus } \\
\text { renginius...Rengti lankstinukus..." (C); }\end{array}$ \\
\hline & Nuoširdus bendravimas & $\begin{array}{l}\text { „...Pedagogai turi...suvokti savo darbo viziją... išklausyti vienas kitą, } \\
\text { priimti pastebejjimus, patarimus...vengti neaiškių pasisakymų, } \\
\text { dviprasmiškų kalbu.. Visuomet išlikti tolerantiškiems...“(D); } \\
\text { „... Gebèjimas priimti kito žmogaus nuomonę...“ (E); } \\
\text { „...Nuoširdus bendravimas..." (F). }\end{array}$ \\
\hline
\end{tabular}

Šaltinis: sudarytas autorių, remiantis atlikto tyrimo duomenimis, 2021

Pusė informantų (3) vieną iš pagrindinių veiksnių, galinčių pagerinti bendradarbiavimą su tèvais ugdant vaikus, turinčius autizmo spektro sutrikimą, nurodè nuoširdu ir teigiama bendradarbiavima. Šiai informantų nuomonei pritaria Vietienè ir Malinauskienė (2015). Autorių teigimu, kokybišką vaiko ugdymąsi galima pasiekti tik nuoširdžiu pedagogų ir tėvų bendravimu ir bendradarbiavimu. Čiuladienė ir Valantino (2016) pabrěžia, kad tėvų ir pedagogų sėkmingas bendradarbiavimas reiškia ne tik informacijos gavimą, bet ir jos pasidalijimą. Autorių nuomone, sėkmingas bendradarbiavimas bus tik tada, kai pedagogai sugebès domėtis tèvų lūkesčiais, pastebèjimais, o nebus jiems apatiški. Šiai nuomonei dalinai pritaria ir informantas (1), kuris nurodè informacijos skleidimo gerinima.

Pedagogų ir tèvų bendradarbiavimas yra priemonè tikslams pasiekti, problemoms išspręsti, bet ne problemoms išvengti. Pasitikẻjimas ugdymo ìstaiga skatinimas ir teigiamos atmosferos gerinimas pasak informantu (2), taip pat sèkmès veiksnys, galintis pagerinti bendradarbiavimo procesą su tèvais, ugdančiais vaikus, turinčius autizmo spektro sutrikimą. Ir tik atsižvelgus ị visus šiuos veiksnius galima tikètis sèkmingo bendradarbiavimo.

Apibendrinant gautus tyrimo rezultatus, galima teigti, kad sèkmès veiksniai, galintys pagerinti bendradarbiavimo su tèvais, ugdančiais vaikus, turinčius autizmo spektro sutrikima, yra šie: pasitikèjimo ugdymo istaiga skatinimas, teigiamos atmosferos, informacijos skleidimo gerinimas, nuoširdus ir teigiamas bendravimas.

\section{Išvados}

1. Išanalizavus mokslinę literatūrą, paaiškejjo, kadautizmo spektro sutrikimas yra - įvairiapusis raidos sutrikimas, dėl kurio pažeidžiamas vaiko fizinis ir psichosocialinis funkcionavimas. Autizmo sutrikimas pasireiškia kalbos, bendravimo sunkumais, socialinių gebejjimų stoka, vaizduotès ir interesų sutrikimais.Vaiko, turinčio autizmo spektro sutrikimą, specialiujų ugdymosi poreikių patenkinimui yra labai svarbus ir reikalingas tėvų, pedagogų ir specialistų bendradarbiavimas ikimokyklinio ugdymo 
procese. Pedagogai ir tèvai susiduria su įvairiomis bendradarbiavimo problemomis, tačiau kiekvienas iš jų jas supranta skirtingai.

2. Atlikus kokybinị tyrimą nustatyta, kad pedagogų ir tėvų bendradarbiavimas ugdant autizmo spektro sutrikimą turinčius vaikus ikimokyklinio ugdymo įstaigoje yra reikšmingas ir reikalingas procesas siekiant vaiko gerovès užtikrinimo. Pedagogų nuomone, tėvų įtraukimui ị ugdymo procesą priimtiniausios ir dažniausiai naudojamos bendradarbiavimo formos yra šios: individualūs pokalbiai ir susitikimai, bendri renginiai, šventės ir išvykos, šiek tiek rečiau - ugdomosios veiklos ir susirinkimai. Pedagogai nurodo tokius bendradarbiavimo metodus ir priemones, susijusias su autizmo spektro sutrikimą turinčių vaikų tẻvais: ịvairūs susitikimai, pokalbiai, susirašinejjimas elektroniniais laiškais, ugdymosi pasiekimų vertinimas ir aptarimas. Pedagogų teigimu, bendradarbiavimo su šeima sèkmę lemia šie veiksniai: pasitikèjimo ugdymo ịstaiga skatinimas, teigiamos atmosferos, informacijos skleidimo gerinimas, nuoširdus ir teigiamas bendravimas.

\section{Literatūra}

1. Ališauskas, A., Ališauskienè, S., Gerulaitis, D., Kaffemanienè, I., Melienè, R., ir Miltenienè, L. (2011). Specialiuju ugdymo poreikiu tenkinimas: Lietuvos patirtis užsienio šaliu kontekste. Šiauliai: Šiauliu universiteto leidykla.

2. Baraldsnes, D. ir Vaškienè, A. (2013). Socialinio pedagogo iššūkiai organizuojant ir teikiant socialinę-pedagoginę pagalbą mokiniams mokykloje. Socialinis darbas, 1 (62), 199-210.

3. Baron-Cohen, S. (2011). Esminis skirtumas: Vyriškos ir moteriškos smegenys.Visa tiesa apie autizma. Vilnius: Baltos lankos.

4. Burvytè, S. (2019). Šeimos ir ikimokykliniu ugdymo instituciju bendradarbiavimas: pozityviosios tèvystès skatinimo aspektas.Socialinis ugdymas, 3 (35), 122-136. Prieiga per internetą: Šeimos ir ikimokyklinių ugdymo institucijų bendradarbiavimas: pozityviosios tėvystès skatinimo aspektas | VDU CRIS

5. Čiuladienè, G. ir Valantinas, A. (2016). Tèvų ir mokyklos bendradarbiavimo gairès: ką atskleidžia kritiški tèvų atsiliepimai apie ugdymo procesą. Acta Paedagogica Vilnensia, 37 (37), 35-47.

6. Encarnacion, S. ir Pozo, P. (2014). Coping Strategies and Parents Positive perceptions of Raising a Child with Autism Spectrum Disorders. Spain: National University of Distance Education

7. Fett-Conte, A., Bossolani-Martins, A., L ir Avanso Rosan, D., B. (2014). Etiology of Autism the Complexity of Risk Factors in Autism Spectrum Disorder. Brasil: Faculty of Psichology. Prieiga per internetą: https://www.intechopen.com/chapters/47503

8. Francescon Cittolin, S. (2018). Cooperation: A Concept Analysis, 9 (2), 28-31.

9. Gelžinytė, I. ir Bagdonas, A. (2016). Šeimų, auginančių 4-5 metų vaikus, dalyvavimas vaikų ugomojoje veikloje. Prieiga per internetą: https://core.ac.uk/reader/75821380

10. Grecucci, A., Siugzdaite, R. ir Job, R. (2016). Advanced neuroimaging methods for studing autism disorder. Switzerland: Frontiers.doi:10.3389/fnins.2017.00533

11. Griciūnaitè, E. (2016). Tèvų ir pedagogų bendradarbiavimas tobulinant ugdymo kokybę ikimo kyklinejje įstaigoje. Prieiga per internetą: https://core.ac.uk/download/pdf/75821367.pdf\#page=79

12. Grigènaitè, J. (2020). Ankstyvojo amžiaus autizmo spektro sutrikimų turinčių vaikų funkcinio elgesio vertinimas bendradarbiaujant šeimoms ir logopedui. Mokslo publikacijos, 1 (41), 103-139.

13. Gustaitienè, I. ir Širiakovienè, A. (2020) Priešmokyklinio ugdymo pedagogų ir tèvų bendravimas ir bendradarbiavimas (Kauno miesto atvejis). Jaunuju mokslinku darbai, 50 (1), 6-13. Prieiga per internetą: doi: https://doi.org/10.21277/jmd.v50i1.283

14. Ivoškuvienè, R. ir Urbutytė, A. (2008). Autistiško vaiko pažinimas šeimoje. Jaunuju mokslininku darbai, 4 (20), 158-163.

15. Juchnevičienè, R., Mačiulienè, D. ir Juškytè, V. (2014). Tèvu, auginančiu vaikus, turinčius autizmo sindroma, nuomone apie dantu éduonies profilaktikos galimybes. Sveikatos mokslai. 24 (6), 35-39.

16. Kaffemanienè, I. ir Žukaité, S. Auklètojų ir logopedų nuostatos ị bendradarbiavimą, ugdant ikimokyklinio amžiaus vaikus. Mokslo publikacijos, 4(20), 169-175. 
17. Kairienè, D. (2010). Komandu narių bendradarbiavimas teikia ankstesnę pagalba vaikui ir šeimai: atvejo analize, 1 (22), 84-96.

18. Kalyva, E. (2013). Stress in Greek Primary Schoolteachers Working Under Conditions of Financial Crisis, Europe's Journal of Psychology, 9 (1), 104-112.

19. Klimavičius, D. (2015). Vaikystès autizmas suaugusiųų amžiuje. Prieiga per internetą:https://www.emedicina.lt/lt/gydytojui/lietuvos_naujienos/v-88.html

20. Leliūgienè, I. ir Simanavičiūtè, G. (2010). Pedagoginis tėvų švietimas kaip sèkmingos vaikų socializacijos prielaida. Mokslo publikacijos. 9 (1), 114-121.

21. Mickevičienè, E., Šinkariova, L. ir Perminas, A. (2009). Vaikų, turinčių autizmo sindromą, tėvų ir motinų depresyvumas.Psichologija, 390, 19-30. doi: 10.15388 / Psichol.2009.0.2597

22. Miltenienè, L. (2004). Pedagogų nuostatos ì specialuji ugdymą ir ugdymo dalyvių bendradarbiavimą: struktūros ir raiškos ypatumai. Specialusis ugdymas:mokslo darbai, 2 (11), 151165.

23. Miltenienè, L. (2005). Mokyklinio amžiaus specialiujų poreikių vaikų ugdymas. Specialusis ugdymas, 2 (13), 34-44.

24. Nacionalinè švietimo agentūra. (2016). Bendrojo ugdymo mokytojų bendrujų ir dalykinių kompetencijų tobulinimas. Prieiga per internetą: https://www.nsa.smm.lt/svietimo-pagalbosdepartamentas/projektai/bendrojo-ugdymo-mokytoju-bendruju-ir-dalykiniu-kompetencijutobulinimas/

25. Nacionalinis medicininès klasifikacijos centras. (2008).TLK-10-AM sisteminis ligų sąrašas. Prieiga per internetą: TLK-10-AM / ACHI / ACS elektroninis vadovas (vlk.lt)

26. Pilkauskienè, A. (2008). Autizmas. Vis dar daug klausimų. Prieiga per internetą: https://www.svei kaszmogus.lt/Vaikams1-1296-Autizmas_Vis_dar_daug_klausimu

27. Samsonienė, L., Bencion Malkin, M., Kairys, J. ir Juozulynas, A. (2017). Šeimų, auginančių vaikus su autizmo spektro sutrikimu, gyvenimo gerovè. Sveikatos mokslai, 27 (3), 76-83.

28. Saveikienė, D. (2018). Tẻvų, auginančių autizmą turinčius vaikus, požiūrio ị vaiko ateitị naratyvas. Tiltai, 79 (1), 125-140.

29. Skučaitè, V. ir Karmazè, E. G. (2011). Padèkime vaikui ịveikti sunkumus: geroji bendradarbiavimomokyklose patirtis. Prieiga per internetą: https://webcache.googleusercontent.com/search?q=cache:5kljrHhlqQ4J:https://sodas.ugdome.lt/ bylos/GENERAL/a4ed3426-15c0-403d-b112-21441ccc7 75f.pdf+\&cd=1\&hl=lt\&ct=clnk\&gl=lt

30. Specialiosios pedagogikos ir psichologijos centras (2011). Metodinès rekomendacijos „Mokomès kartu“. Prieiga per internetą: http://www.esparama a.lt/es_parama_pletra/failai/ESF produktai/2011 metodines rekomendacijos Mokomes kartu

31. Šavrina, B., Grundey, D. ir Berzina, K. (2008). Cooperation-the form of sustainable tourism industry in Latvia. Baltic Journal on Sustainability, 14 (2), 151-161.

32. Ulevičiūtè, R. ir Gaigalienè, M. (2008). 3-7 metų vaikų autistų tèvų požiūris ị struktūruoto mokymo taikymą. Mokslo publikacijos, 5, 249-290.

33. Vaicekauskienè, V. (2003). Neigaliu vaiku ugdytoju požiūris i bendradarbiavima. Socialinis darbas, 1 (3), 57-71.

34. Vietienè, I. ir Malinauskienè, D. (2015). Tẻvų požiūris ị bendradarbiavimo raišką ikimokyklinèje bendruomenèje. Mokslo publikacijos, 24 (1), 101-113.

35. Vijūnaitè, J. ir Slušnienè, G. (2018). Informacinių technologijų panaudojimo galimybès bendradarbiavimo su tẻvais procese ikimokyklinio ugdymo įstaigoje. Prieiga per internetą: https://www.kvk.lt/wp-content/uploads/2020/12/Studijos-verslas-visuomene_2018.pdf\#page=114

36. Zvicevičienè, S. ir Aleksienè, V. (2008). Lietuvos etnochoreografija autistiškiems vaikams: ugdymo ir terapijos aspektai: mokslo studija. Vilnius: Ciklonas. 


\title{
THE COLLABORATION BETWEEN EDUCATORS AND PARENTS IN EDUCATING CHILDREN WITH AUTISM SPECTRUM DISORDER
}

\author{
Jūratė Kazlauskienė, Šilutė kindergarten,, Star“6 \\ Aurelija Valaitienė, Klaipeda State University of Applied Sciences
}

\begin{abstract}
Summary
Autism spectrum disorder is a heterogeneous group of neurodevelopmental disorders characterized by persistent impairments in social communication and interaction (Zvicevičienè, Aleksienè, (2008). The causes of autism spectrum disorder remain unclear to this day (Grecucci, Siugzdaite, Job, 2016). Autism spectrum disorder can cause significant social, communication and behavioral problems. Children with this disorder are able to communicate, behave appropriately and learn, but unlike most other people, some need more help, and some need less . Autism spectrum disorder is widely known in the modern world, but not enough is known about it in Lithuania (Juchnevičienè, Mačiulienė, Juškyte், 2014). There is a lack of research that reveals the peculiarities of cooperation between parents and educators with children with autism spectrum disorder in preschool age. Only a harmonious cooperation between educators, parents and professionals can help children to successfully socialise in society (Pozo, 2017). Educators and parents are the two interfaces responsible for educating and preparing the child for independent living. Their cooperation is essential and necessary, as educators and parents can only work together to achieve excellent results. A good relationship between educators and parents can strengthen the cooperation between parents and the pre-school institution, which is essential for achieving common goals. This is the reason for the relevance of the chosen topic.

Research problem: how do educators and parents work together to educate children with autism spectrum disorder?

Study object: cooperation between parents and educators

Aim of the study: to analyze the collaboration between educators and parents in the education of children with autism spectrum disorder.

\section{Objectives of the study}

1.To provide theoretical insight into the peculiarities of cooperation between educators and parents in the education of children with autism spectrum disorder.

2. To empirically identify forms and methods of cooperation between educators and parents in the education of children with autism spectrum disorder.

Research methods: analysis of scientific literature, structured interviews, qualitative analysis of research results.

The definition of autism spectrum disorder and the developmental aspects of children with autism spectrum disorder suggest that autism spectrum disorder is a multifaceted developmental disorder that impairs the child's physical and psychosocial functioning. Autism spectrum disorder manifests itself in a variety of ways: difficulties with language, communication, social skills, imagination and interests. For a child with an autism spectrum disorder, cooperation between parents, educators and professionals in the pre-school education process is essential and necessary to meet the special educational needs of the child. Educators and parents face a variety of cooperation problems, but each perceives them differently. The results of the study revealed that cooperation between educators and parents in the education of children with autism spectrum disorder in pre-school education is a significant and necessary process for the well-being of the child. Educators consider that the most acceptable and commonly used forms of cooperation to involve parents in the educational process are: individual conversations and meetings, joint events, festivals and outings, and, to a lesser extent, educational activities and meetings. Educators indicate the following methods and means of cooperation with parents of children with autism spectrum disorder: various meetings, conversations, emails, assessment and discussion of educational achievements.
\end{abstract}

Keywords: autism spectrum disorder, parent and educator cooperation, education. 